\title{
PERBEDAAN KUALITAS HIDUP BERDASARKAN SHORT FORM-36 ANTARA PENDERITA STROKE ISKEMIK SERANGAN PERTAMA DENGAN KEDUA
}

\author{
DIFFERENCES QUALITY OF LIFE BASED ON SHORT FORM-36 BETWEEN \\ FIRST AND SECOND ATTACK ISCHEMIC STROKE PATIENTS
}

Nazwan Hassa, * Jimmy Eko Budi Hartono, * Dwi Pudjonarko*

\section{ABSTRACT}

Introduction: Stroke is the biggest cause of physical disability, emotional, and social life in adults. The recurrent stroke let to decreased the quality of life.

Aims: To know whether there is a difference in quality of life based on the Short Form-36 (SF-36) between first and second attack ischemic stroke patients.

Methods: Observational analytic with retrospective cross sectional study in Neurology Polyclinic Dr. Kariadi Hospital, Semarang form July-September 2016. Inclusion criteria are patients with first or second attack of ischemic stroke, level education at least elementary school, age between 50-70 years old, and last attack 4 week or less before the sampling conducted. Quality of life were scored based on SF-36 between first and second attack patients. T-test and MannWhitney were used to analyze the data.

Results: Fifty subject (25 in each group) included with mean age 57.72 (51-65) and 60.24 (51-70) years old in first attack and second attack group respectively. Older age showed lower quality of life score. The quality of life score is lower in older, stroke onset $>1$ year, and lower education. There was significant quality of life score difference between first and second attack group. Quality of life patients with first attack is better significantly compared to the second attack group in functional and physical domain, energy, and total score.

Discussion: There is a significant difference in quality of life based on the SF-36 between first and second attack ischemic stroke patients.

Keywords: Ischemic stroke, quality of life, SF-36

\section{ABSTRAK}

Pendahuluan: Stroke merupakan penyebab terbesar ketidakmampuan fisik, emosi, dan kehidupan sosial pada orang dewasa. Serangan stroke berulang menyebabkan peningkatan risiko penurunan kualitas hidup.

Tujuan: Mengetahui perbedaan kualitas hidup pasien stroke iskemik serangan pertama dan kedua berdasarkan Short Form-36 (SF-36).

Metode: Penelitian analitik observasional secara potong lintang retrospektif di Poliklinik Neurologi RSUP Dr. Kariadi, Semarang pada bulan Juli-September 2016. Kriteria inklusi adalah pasien stroke iskemik serangan pertama atau kedua, berpendidikan minimal SD atau sederajat, berusia antara 50-70 tahun, dan mengalami serangan stroke terakhir minimal 4 minggu sebelum penelitian. Dilakukan penilaian skor kualitas hidup berdasarkan SF-36 antara pasien stroke iskemik serangan pertama dengan kedua. Analisis menggunakan uji T-tes dan Mann-Whitney.

Hasil: Terdapat 50 subjek yang terdiri dari masing-masing 25 subjek pada kelompok dengan stroke iskemik serangan pertama dan kelompok dengan serangan kedua dengan rerata usia 57,72 (51-65) tahun dan 60,24 (51-70) tahun. Usia yang semakin meningkat menunjukkan skor kualitas hidup semakin menurun. Skor kualitas hidup lebih rendah pada usia yang lebih tinggi, lama menderita stroke $>1$ tahun, dan pendidikan yang lebih rendah. Didapatkan perbedaan bermakna antara rerata skor kualitas hidup pasien stroke serangan pertama dan kedua. Kualitas hidup subjek pada serangan stroke pertama lebih baik secara bermakna dibandingkan pada kelompok serangan kedua, dalam domain fungsi dan peranan fisik, energi, serta total skor secara keseluruhan.

Diskusi: Terdapat perbedaan bermakna kualitas hidup berdasarkan SF-36 antara pasien stroke iskemik serangan pertama dengan kedua.

Kata kunci: SF-36, skor kualitas hidup, stroke iskemik

*Bagian Neurologi FK Universitas Diponegoro/RSUP Dr. Kariadi, Semarang. Korespondensi: nazwanhassa@gmail.com.

\section{PENDAHULUAN}

Stroke adalah sindroma klinis akut dengan gejala berupa gangguan fungsi otak baik secara fokal maupun global atau dapat menimbulkan kematian atau kecacatan yang menetap lebih dari 24 jam tanpa penyebab lain kecuali gangguan vaskuler. 
Adapun definisi stroke iskemik adalah suatu episode disfungsi neurologis yang disebabkan oleh infark fokal serebral, medula spinalis dan retina. ${ }^{1}$ Prevalensi penderita stroke di Asia 50-400 orang per 100000 penduduk per tahun. ${ }^{2}$

Stroke merupakan penyebab terbesar ketidakmampuan fisik, emosi, dan kehidupan sosial pada orang dewasa. ${ }^{3}$ Efek stroke dapat berupa kelumpuhan, defisit fungsi kognitif, kesulitan bicara, kesulitan emosional, masalah dalam kehidupan sehari-hari, serta kesakitan. ${ }^{4}$ Ketidakmampuan fisik, emosi, dan kehidupan sosial pasien stroke tentu saja memengaruhi kualitas kesehatannya. Seseorang yang sehat akan mempunyai kualitas hidup yang baik, begitu pula kualitas hidup yang baik tentu saja akan menunjang kesehatan. ${ }^{5-6}$

Pengukuran kualitas hidup terkait kesehatan pada pasien stroke tersebut untuk mengetahui reaksi pasien terhadap penyakitnya, meningkatkan usahausaha perawatan suportif dan mengevaluasi terapi yang telah dilakukan. Pengukuran tersebut biasanya meliputi elemen fungsional, fisik, psikologis, dan sosial dari pasien. ${ }^{7-8}$

Keadaaan pascastroke merupakan faktor resiko terjadinya stroke ulang. Meta analisis dari Mohan $\mathrm{dkk}$, menyatakan bahwa risiko serangan ulang adalah $3,1 \%$ pada 30 hari, $11,1 \%$ pada 1 tahun, $26,4 \%$ pada 5 tahun. Data lain menyebutkan $12-14 \%$ pasien stroke mengalami serangan ulang pada tahun pertama dan $30 \%$ terjadi dalam waktu 5 tahun pascastroke. ${ }^{7}$

Resiko kematian dan ketidakmampuan setelah stroke meningkat dengan adanya kejadian stroke berulang tersebut. Adanya peningkatan resiko ketidakmampuan tersebut juga menunjukkan adanya peningkatan resiko penurunan kualitas hidup pada pasien serangan stroke berulang. ${ }^{4}$

Pengukuran kualitas hidup akan dilakukan dengan menggunakan kuesioner Short Form-36 (SF36) yang merupakan salah satu bentuk kuesioner umum yang banyak dipakai pada penelitian-penelitian mengenai kualitas hidup dan telah diterjemahkan dan divalidasi dalam versi bahasa Indonesia. ${ }^{8}$ Selain itu kuesioner Short Form (SF-36) memiliki bahasa yang sederhana sehingga lebih mudah dipahami dan memiliki komponen dimensi penilaian kualitas hidup yang lebih lengkap dibandingkan kuesioner yang lain yaitu dimensi fisik dan mental. ${ }^{8}$

Pentingnya pengukuran kualitas hidup terkait kesehatan pada pasien stroke iskemik dan adanya peningkatan resiko ketidakmampuan pada pasien stroke iskemik serangan kedua mendorong peneliti untuk melaksanakan penelitian dengan tujuan membandingkan hasil pengukuran kualitas hidup terkait kesehatan antara pasien stroke iskemik serangan pertama dengan kedua.

\section{TUJUAN}

Mengetahui perbedaan skor kualitas hidup pasien stroke iskemik serangan pertama dengan kedua berdasarkan Short Form-36 (SF-36).

\section{METODE}

Penelitian ini dilakukan di Poliklinik Neurologi RSUP Dr. Kariadi, Semarang dengan rancangan potong lintang retrospektif pada bulan Juli-September 2016. Kriteria inklusi adalah pasien stroke iskemik serangan pertama atau kedua, pendidikan minimal SD atau sederajat, usia antara 50-70 tahun, serangan stroke terakhir minimal 4 minggu sebelum penelitian. Kriteria eksklusi adalah pasien mengalami gangguan kesadaran atau afasia saat dilakukan pemeriksaan.

Selanjutnya subjek dikelompokkan dalam dua kelompok, yaitu subjek dengan serangan stroke iskemik pertama dan kedua. Dilakukan anamnesis, pemeriksaan fisik dan neurologis, serta penilaian kualitas hidup menggunakan kuesioner SF-36. Kuesioner ini sudah divalidasi yang terdiri dari domain fungsi fisik, peranan fisik, peranan emosi, energi/vitality, kesehatan jiwa, fungsi sosial, rasa nyeri, dan kesehatan umum.

Penelitian ini telah mendapat persetujuan dari Komisi Etik Penelitian Kedokteran FK UNDIP/ RSUP Dr. Kariadi, Semarang. Analisis statistik menggunakan SPSS 23.00 for windows. Dilakukan uji normalitas data menggunakan Sapiro-Wilk, karena subjek penelitian berjumlah 50. Analisis bivariat untuk variabel dengan distribusi normal digunakan T-test tidak berpasangan dan untuk distribusi data tidak normal menggunakan uji Man-Whitney.

\section{HASIL}

Terdapat 50 subjek yang terdiri dari masingmasing 25 subjek pada kelompok dengan stroke iskemik serangan pertama dan kelompok dengan 
serangan kedua (Tabel 1). Mayoritas subjek adalah laki-laki dan berpendidikan $>9$ tahun. Walaupun tidak bermakna, namun subjek dengan serangan stroke kedua mempunya rerata usia yang lebih tinggi dibandingkan kelompok yang baru mengalami stroke pertama kali $[60,24(51-70)$ tahun vs $57,72(51-65)$ tahun].

Tabel 1. Karakteristik Subjek Penelitian $(n=50)$

\begin{tabular}{lccc}
\hline \multirow{2}{*}{$\begin{array}{l}\text { Karakteristik } \\
\text { Subjek }\end{array}$} & $\begin{array}{c}\text { Pertama } \\
(\mathbf{n = 2 5})\end{array}$ & $\begin{array}{c}\text { Kedua } \\
(\mathbf{n = 2 5})\end{array}$ & $\mathbf{p}$ \\
\cline { 2 - 3 } & $\mathbf{n ~ ( \% )}$ & $\mathbf{n ~ ( \% )}$ & \\
\cline { 2 - 3 } $\begin{array}{l}\text { Usia (rerata/ } \\
\text { min-maks) }\end{array}$ & $57,72(51-65)$ & $60,24(51-70)$ & \\
- $\quad 51-60$ & $19(76)$ & $12(48)$ & 0,074 \\
- $\quad 61-70$ & $6(24)$ & $13(52)$ & \\
Jenis kelamin & & & \\
- $\quad$ Laki-laki & $13(52)$ & $15(60)$ & 0,569 \\
- $\quad$ Perempuan & $12(48)$ & $10(40)$ & \\
$\begin{array}{l}\text { Pendidikan } \\
\text { - } \quad \leq 9 \text { tahun }\end{array}$ & $7(28)$ & $9(36)$ & 0,590 \\
- $\quad>9$ tahun & $18(72)$ & $16(64)$ & \\
$\begin{array}{l}\text { Serangan } \\
\text { stroke terakhir }\end{array}$ & & & \\
- $\quad<1$ tahun & $13(52)$ & $11(44)$ & 0,571 \\
- $>1$ tahun & $12(48)$ & $14(56)$ & \\
\hline
\end{tabular}

Rerata total skor kualitas hidup pada kelompok subjek serangan stroke pertama didapatkan lebih tinggi pada subjek laki-laki (1461), sedangkan pada kelompok subjek serangan stroke kedua lebih tinggi pada subjek perempuan (1227). Adapun rerata total skor kualitas hidup pada kedua kelompok didapatkan paling tinggi pada subjek dengan pendidikan tinggi $(>9$ tahun), yaitu 2847 dan 2442. Skor tertinggi terdapat pada kelompok subjek dengan lamanya menderita stroke $<1$ tahun (1445 dan 1265). Demikian pula rerata total skor penderita stroke iskemik serangan pertama lebih tinggi dari total skor penderita stroke iskemik serangan kedua secara bermakna $(p<0,05)$, seperti pada Tabel 2.

Berdasarkan rerata skor dari domain (8 dimensi) antara stroke serangan pertama dengan kedua, didapatkan perbedaan yang bermakna pada dimensi fungsi dan peranan fisik, energi, serta total skor (Tabel 3). Kualitas hidup subjek pada serangan stroke
Tabel 2. Rerata Total Skor Kualitas Hidup Subjek

\begin{tabular}{|c|c|c|c|}
\hline \multirow[b]{2}{*}{ Karakteristik } & \multicolumn{2}{|c|}{ Rerata Total Skor } & \multirow[b]{2}{*}{$\mathbf{p}$} \\
\hline & $\begin{array}{c}\text { Serangan I } \\
(n=25)\end{array}$ & $\begin{array}{c}\text { Serangan II } \\
\quad(n=25)\end{array}$ & \\
\hline \multicolumn{4}{|l|}{ Usia } \\
\hline - $51-60$ & 2776 & 2128 & 0,024 \\
\hline - $61-70$ & 1363 & 2492 & \\
\hline \multicolumn{4}{|l|}{ Jenis kelamin } \\
\hline - Laki-laki & 1461 & 1127 & 0,049 \\
\hline - Perempuan & 1286 & 1227 & \\
\hline \multicolumn{4}{|l|}{ Pendidikan } \\
\hline - $<9$ tahun & 2546 & 2367 & 0,030 \\
\hline$\bullet>9$ tahun & 2847 & 2442 & \\
\hline \multicolumn{4}{|c|}{ Serangan terakhir } \\
\hline$\bullet<1$ tahun & 1445 & 1265 & 0,027 \\
\hline - $>1$ tahun & 1303 & 1090 & \\
\hline
\end{tabular}

pertama lebih baik secara bermakna dibandingkan pada kelompok serangan kedua, dalam domain fungsi dan peranan fisik, energi, serta total skor secara keseluruhan.

Tabel 3. Hubungan antara Domain dengan Total Skor Kualitas Hidup

\begin{tabular}{lccc}
\hline Dimensi Kualitas Hidup & $\begin{array}{c}\text { Stroke } \\
\text { I }\end{array}$ & $\begin{array}{c}\text { Stroke } \\
\text { II }\end{array}$ & p \\
\hline Fungsi Fisik & 31 & 21 & $0,005^{* \beta}$ \\
Peranan Fisik & 16 & 4 & $0,006^{* \beta}$ \\
Peranan Emosi & 9 & 8 & $0,809^{\beta}$ \\
Energi & 50 & 42 & $0,010^{* \alpha}$ \\
Kesehatan Jiwa & 57 & 50 & $0,838^{\alpha}$ \\
Fungsi Sosial & 49 & 46 & $0,635^{\beta}$ \\
Rasa Nyeri & 58 & 54 & $0,415^{\beta}$ \\
Kesehatan Umum & 46 & 44 & $0,761^{\beta}$ \\
Total Skor & 38 & 32 & $0,031^{* \beta}$ \\
\hline
\end{tabular}

*Bermakna $(\mathrm{p}<0,05) ;{ }^{\alpha}$ T-test; ${ }^{\beta} \mathrm{Uji}$ Mann-Whitney.

\section{PEMBAHASAN}

Adanya variasi rerata skor dapat menggambarkan bahwa usia subjek memengaruhi skor kualitas hidup terkait kesehatan. Larsen dkk menyebutkan bahwa skor pada dimensi energi, fungsi sosial, peran emosi, dan kesehatan jiwa pasien stroke usia 45-64 tahun lebih rendah dibanding pada usia yang lebih tua. Hal ini disebabkan pasien pada usia pertengahan memerlukan usaha lebih banyak untuk menyesuaikan 
keadaan kehidupan yang baru setelah serangan stroke. Rentang usia tersebut adalah masa aktif dan produktif, sehingga dengan menderita stroke maka kemampuan seseorang dalam beraktifitas sehari-hari, bekerja, dan bersosialisasi sangat berkurang. ${ }^{31}$ Pada penelitian ini, meskipun dengan bertambahnya usia terdapat variasi skor kualitas hidup, namun masih bisa disimpulkan bahwa usia memiliki pengaruh terhadap nilai skor kualitas hidup $(\mathrm{p}=0,024)$.

Rerata total skor kualitas hidup penelitian ini didapatkan lebih tinggi pada laki-laki kelompok subjek serangan stroke pertama, sesuai dengan penelitian Leoo dkk, yaitu skor kualitas hidup ditemukan lebih rendah pada perempuan. ${ }^{11}$ Namun pada kelompok serangan stroke kedua penelitian ini mendapatkan perempuan memiliki skor lebih tinggi dari pada laki-laki. Rastenyte menyatakan perempuan memiliki kestabilan mental atau psikis dibandingkan laki-laki dalam beradaptasi menghadapi penyakit yang diderita. ${ }^{7}$

Rerata total skor kualitas hidup pada kedua kelompok didapatkan paling tinggi pada subjek dengan pendidikan tinggi ( $>9$ tahun), sedangkan rerata skor terendah untuk serangan pertama pada pendidikan menengah pertama (SLTP) dan serangan stroke kedua pada tingkat sekolah dasar (SD). Nicholas-Larsen dkk menyebutkan skor kualitas kesehatan dipengaruhi oleh tingkat pendidikan, semakin tinggi pendidikan penderita stroke semakin tinggi skor kualitas kesehatan. ${ }^{13}$

Pada penelitian ini skor tertinggi didapatkan pada tingkat pendidikan perguruan tinggi, dikarenakan semakin tinggi tingkat pendidikannya penderita stroke maka semakin luas wawasan mengenai kesehatan dan upaya-upaya untuk memperbaiki kualitas kesehatannya. ${ }^{14} \mathrm{Hal}$ ini juga terlihat pada subjek dengan pendidikan SD memiliki rerata skor yg lebih rendah pada domain emosi, kesehatan jiwa, fungsi sosial, dan kesehatan umum dibanding yang berpendidikan SLTP.

Pada kedua kelompok subjek serangan stroke pertama dan berulang didapati rerata total skor kualitas hidup lebih tinggi pada subjek yang menderita stroke kurang $<1$ tahun (14445 dan 1265). Hal ini sesuai dengan Patel dkk, bahwa skor kualitas hidup terkait kesehatan pada pasien stroke mengalami peningkatan pada fase pascastroke, namun peningkatannya tidak signifikan pada selang waktu satu tahun setelah serangan stroke. ${ }^{15}$ Kemungkinan pada penderita stroke fase awal ( $<1$ tahun) masih memiliki semangat yang cukup baik dalam melakukan berbagai upaya kesehatan untuk memperbaiki kondisi kesehatannya.

Total skor kualitas hidup terkait kesehatan pada subjek dengan stroke iskemik serangan pertama lebih tinggi secara bermakna $(\mathrm{p}<0,05)$ dibandingkan subjek stroke iskemik serangan kedua, yaitu pada dimensi fungsi fisik, peranan fisik, dan energi (Tabel 3). Komponen fisik diwakili oleh dimensi fungsi fisik, peranan fisik, rasa nyeri, dan kesehatan umum dalam pengukuran dengan skor kualitas hidup berdasarkan SF-36. ${ }^{3}$ Dalam sebuah penelitian yang juga menggunakan SF-36 menyebutkan bahwa dimensi fungsi fisik dan peranan fisik dalam kualitas hidup terkait kesehatan merupakan dimensi yang paling dipengaruhi dengan keadaan pascastroke. ${ }^{3}$

Skor fungsi fisik dan peranan fisik yang rendah menggambarkan bahwa subjek masih mengalami keterbatasan dan kesulitan saat menjalani aktivitas fisik mereka. ${ }^{3}$ Setelah mengalami serangan stroke berulang, pasien memiliki kecenderungan untuk lebih mengalami ketidakmampuan dan kecacatan fisik dibandingkan orang dengan serangan stroke pertama. ${ }^{16}$

Hal itu mengindikasikan pentingnya menentukan prognosis, rencana terapi, dan rehabilitasi yang tepat terhadap kejadian stroke kedua, oleh karena pasien dengan stroke kedua dapat meningkatkan kemampuan fisiknya melalui terapi dan rehabilitasi yang tepat. ${ }^{16}$ Adapun komponen mental dalam kualitas hidup terkait kesehatan diwakili oleh dimensi energi, fungsi sosial, peranan emosi, dan kesehatan jiwa. ${ }^{17}$ Berdasarkan data-data yang diperoleh, dalam empat dimensi tersebut hanya dimensi energi (vitality) yang memiliki perbedaan bermakna antara skor dua kelompok subjek (Tabel 3).

Kondisi ini dimungkinkan karena komponen mental pada pasien stroke lebih dipengaruhi oleh faktor selain serangan stroke berulang. NicholasLarsen dkk menyebutkan bahwa peran keluarga sangat memengaruhi komponen mental dalam kualitas hidup terkait kesehatan pasien stroke. ${ }^{12}$ Dimensi kesehatan jiwa pada subjek yang menikah ditemukan lebih 
rendah secara signifikan dibandingkan subjek yang tidak menikah tetapi tinggal dengan keluarganya.

Faktor lain yang juga memengaruhi adalah kemampuan komunikasi pasien stroke. Pasien stroke yang mengalami kesulitan dalam komunikasi seperti afasia maupun disartria cenderung mengalami penurunan dalam dimensi fungsi sosial. Adanya hal tersebut menyebabkan pasien stroke sering mengalami respons emosi yang berlebihan. Mereka juga sering mengeluhkan pengalaman yang memalukan akibat adanya gangguan komunikasi tersebut. ${ }^{12}$ Dalam penelitian ini, pasien yang mengalami gangguan komunikasi yang berat dieksklusikan, sehingga pengaruh faktor komunikasi dalam fungsi sosial dihilangkan.

Penelitian ini memiliki beberapa kelemahan, antara lain tidak semua faktor yang memengaruhi kualitas hidup terkait kesehatan dieksklusikan, yaitu faktor risiko stroke yang memengaruhi kualitas hidup terkait kesehatan seperti riwayat diabetes melitus (DM) dan penyakit jantung iskemik sebelumnya, faktor penyakit penyerta yang memengaruhi kualitas hidup berdasarkan SF-36 (stroke yang diikuti oleh atrial fibrilasi, stroke dengan faktor pemberat hipertensi, DM, artritis, kecacatan, dan ansietas, serta terapi rehabilitasi pada subjek penelitian).

Subjek penelitian juga tidak dibedakan mengikuti terapi rehabilitasi pascastroke atau tidak, serta luas dan letak lesi stroke iskemik. ${ }^{12}$ Selain itu, SF-36 merupakan kuesioner yang bersifat umum, sehingga dimungkinkan tidak dapat menggambarkan bagaimana sesungguhnya akibat spesifik stroke terhadap kualitas hidup terkait kesehatan. Simensi dalam SF-36 dilaporkan tidak dapat menggambarkan level fungsi sosial pasien stroke dikarenakan terlalu terbatasnya poin pertanyaan untuk fungsi sosial. ${ }^{20-21}$

\section{KESIMPULAN}

Terdapat perbedaan pada beberapa dimensi kualitas hidup berdasarkan SF-36 antara pasien stroke iskemik serangan pertama dengan kedua. Kualitas hidup subjek pada serangan stroke pertama lebih baik secara bermakna dibandingkan pada kelompok serangan kedua, dalam domain fungsi dan peranan fisik, energi, serta total skor secara keseluruhan.

\section{DAFTAR PUSTAKA}

1. Sacco RL, Kasner SE, Broderick JP, Caplan LR, Culebras A, Elkind MS, dkk. An updated definition of stroke for the 21st century. Stroke. 2013:44(7):2064-89.

2. Markus HS. An introduction to stroke. Dalam: Markus HS, editor. Strokes genetics. New York: Oxford University Press; 2013. h. 2-3.

3. Santalucia P, Pezzela FR, Sessa M, Monaco S, Targono G, Anticoli S, dkk. Sex differentin clinical presentation, severity and outcome of stroke: result from a hospital-based registry. European J Internal Med. 2013;24(2):167-71.

4. Reeves MJ, Bushnell CD, Howard G, Gargano JW, Duncan PW, Lync G, dkk. Sex differences in stroke: epidemiology, clinical presentation, medical care, and outcomes. Lancet Neurol. 2012;7(10):915-26.

5. Bustami M, editor. Advance neuro critical case support. Jakarta: Indonesia Neurological Associated; 2010. h. 1.

6. Åström M, Asplund K. Handicap and quality of life after stroke. Dalam: Bogousslavsky J, editor. Long term effects of stroke. New York: Marcel Dekker. 2015. h. 25-48.

7. Rastenytė D. Measurement of quality of life in stroke patients. Medicina (Kaunas). 2010:42(9):709-16.

8. De Haan RD, Aaronson N, Limburg M, Hewer RL, Van Crevel H. Measuring quality of life in stroke. Stroke. 2013;24(2):320-7.

9. Harmaini F. Uji keandalan dan kesahihan formulir European Quality of Life - 5 Dimensions (EQ-5D) untuk mengukur kualitas hidup terkait kesehatan pada usia lanjut di RSUPNCM. Indonesia [tesis.]. Depok: Universitas Indonesia; 2006.

10. Fayers PM, Machin D, editor. Quality of life: the assessment, analysis, and interpretation of patientreported outcomes. Edisi ke-2. London: Jhon Wiley \& Sons Ltd; 2010. h. 4-5.

11. Leoo T, Lindgren A, Petersson J, Von Arbin M. Risk factors and treatment at recurrent stroke onset: results from the Recurrent Stroke Quality and Epidemiology (RESQUE) study. Cerebrovasc Dis. 2012:25(3)254-60.

12. Nichols-Larsen DS, Clark PC, Zeringue A, Greenspan A, Blanton S. Factors influencing stroke survivors' quality of life during subacute recovery. Stroke. 2011;36(7):1480-4.

13. RAND. Scoring instructions for the 36 -item short form survey. RAND Corporation [serial online]. 2009 [diunduh 16 Februari 2015]. Tersedia dari: RAND Health.

14. De Haan RJ, Limburg M, Van der Meulen JH, Jacobs HM, Aaronson NK. Quality of life after stroke. Stroke. 2011;26(3):402-8. 
15. Patel MD, Tilling K, Lawrence E, Rudd AG, Wolfe CD, McKevitt C. Relationships between long-term stroke disability, handicap and health-related quality of life. Age and Ageing. 2013:35(3):273-9.

16. Santalucia P, Pezzela FR, Sessa M, Monaco S, Targono G, Anticoli S, dkk. Sex differentin clinical presentation, severity and outcome of srtoke: result from a hospital-based registry. European J Internal Med. 2013:24(2)167-71.

17. Australian Health Outcomes Collaboration. SF36® health survey (Version 1.0). Instrument review. AHOC; 2012.

18. Ware JE, Kosinski M, Gandek B. SF-36® health survey; manual \& interpretation guide. Quality Metric Incorporated: Boston; 2011.
19. Endres M, Dirnagl U, Moskowitz MA. The Ischemic Cascade and mediators of ischemic injury. Handb Clinical Neurology. 2009:92(3):31-41.

20. Corso G, Bottachi E, Morrosini MV, Tosi P, Caligiana $\mathrm{L}$, Lia C, dkk. Outcomes predictors in first-ever ischemic stroke patients: a population based study. Int SchRes Notice. 2014;2014:904647.

21. Perwitasari DA. Development the validation of Indonesian version of SF-36 questionairre in cancer disease. Indonesian J Pharm. 2012:23(4):248-53. 